\title{
Effect of Intercropping of Angelica sinensis with Garlic on its Growth and Rhizosphere Microflora
}

\author{
X.H. Zhang ${ }^{1,2,3}$, D.Y. Lang ${ }^{4}$, E.H. Zhang ${ }^{2 *}$ and Y.J. Zhang ${ }^{5}$ \\ ${ }^{1}$ College of Pharmacology, Ningxia Medical University, Yinchuan 750004, China \\ ${ }^{2}$ College of Agronomy, Gansu Agricultural University, Lanzhou 730070, China \\ ${ }^{3}$ Ningxia Engineering and Technology Research Center for Modernization of Hui Medicine, Yinchuan 750004, China \\ ${ }^{4}$ Laboratory Animal Center, Ningxia Medical University, Yinchuan 750004, China \\ ${ }^{5}$ Hexi ecological and oasis agricultural research institute, Hexi University, Zhangye 734000, China \\ *For correspondence: zhang2013512@163.com; zhangeh@gsau.edu.cn
}

\begin{abstract}
Aims and Methods A pot experiment was carried out to determine the effect of Angelica sinensis intercropped with garlic on A. sinensis growth and soil microbial communities in rhizosphere soil of $A$. sinensis under the scheme of $A$. sinensis intercropped with garlic. Results Soil microbial community was changed and bacteria functional group diversity was increased, and $A$. sinensis growth was improved when A. sinensis intercropped with garlic under the continuous cropping condition. Also, it shows that intercropping significantly increased root dry weight, and much less substantially shoot dry weight and plant height. Relative to the control, the activity of superoxide dismutase, peroxidase and catalase was increased by $80.00,243.41$ and $37.13 \%$, respectively, but the content of malondialdehyde was decreased by $11.67 \%$, along with a $70.13 \%$ yield improvement of A. sinensis, and $50.00 \%$ and $10.20 \%$ essential oil and alcohol-soluble extract increasing, respectively. The result also showed that the population of bacteria, aerobic cellulose-decomposing bacteria, organic phosphorus-solubilizing bacteria, inorganic phosphorus-solubilizing bacteria and potassium-solubilizing bacteria in rhizosphere soil were promoted in intercropping in vigorous growth stage. The abundance of aerobic cellulose-decomposing bacteria, organic phosphorussolubilizing bacteria and potassium-solubilizing bacteria in intercropping soils changed at the rootstock thickening. Although the total population of functional groups in intercropping A. sinensis rhizosphere soils was lower than in monocroping system, community diversity and evenness increased and dominance concentration decreased. Conclusions Intercropping A. sinensis with garlic can alleviate the soil sickness of A. sinensis. (C) 2015 Friends Science Publishers
\end{abstract}

Keywords: Angelica sinensis; Soil sickness; Soil microbial community; Intercropping

Abbreviations: AB - Ammonifying bacteria; ACDB - Aerobic cellulose-decomposing bacteria; OPSB - Organic phosphorus-solubilizing bacteria; IPSB - Inorganic phosphorus-solubilizing bacteria; KSB - Potassium-solubilizing bacteria; SOD - Superoxide dismutase; POD - Peroxidase; CAT - Catalase; MDA - Malondialdehyde; FM - Fresh mass; NBT Nitroblue tetrazolium; CFU - Colony forming units; LSD - Least significant difference; ROS - Reactive oxygen species

\section{Introduction}

Angelica sinensis (Oliv.) Diels, a perennial herb belonging to family Apiaceae, is commonly used in Traditional Chinese Medicine since ancient times (Zhang and Cheng, 1989). A. sinensis is widely used as an ingredient in cosmetic and health beverage at present (Ma et al., 2002; Chen, 2004). In order to meet its demand, continuously cropped area with $A$. sinensis has increased sharply in the last decade. Continuous cropping of $A$. sinensis in the same fields has resulted in plant growth inhibition, plant mortality and Ditylenchus destructor infestation, which result in the reduced yield and quality (Zhang et al., 2009). At present, the soil sickness has become one of the major constrains in
A. sinensis cultivation.

It is generally known that continuous cropping can affect crop growth and development, decrease yield and quality, and increase disease occurrence in most conditions (Wu et al., 2007; Dai et al., 2009; Zhang et al., 2011). Soil sickness is usually found in agricultural crops, especially in medicinal plant (Zhang et al., 2005; He et al., 2009; Yin et al., 2009). Soil sickness may be attributed to autotoxicity, soil microflora imbalance and changes in soil physiochemical properties (Young, 1984; Yu and Matsui, 1994). Previous studies report that build-up of plant pathogens is one of the major causes in soil sickness in Cistus ladanifer (Hassan et al., 1989), peach (Benizri et al., 2005), cucumber (Yao et al., 2006), Rehmannia glutinosa 
(Chen et al., 2007), Liriope (Zhao et al., 2010), while autotoxicity has been reported to be one of the major causes in soil sickness in cucurbit crops (Yu et al., 2000), alfalfa (Segiun et al., 2002), Cistus ladanifer (Alías et al., 2006), cucumber (Yao et al., 2006) and wheat (Wu et al., 2007). In many cases, soil microorganism played either direct or indirect role in yield reduction (Manici et al., 2003; Hu et al., 2006). In conclusion, the cause of soil sickness is complex. Previous studies have identified some methods to manage soil sickness, such as root stock grafting (Lv et al., 2000), breeding for resistant varieties (Duan et al., 2002), and biocontrol (Haggag, 2002). However, these methods have their limitations, and there was no a method could be solve soil sickness completely.

Intercropping is a system, where two or more crop species are grown in the same field in the same season (Ofori and Stern, 1987). It is an ancient and traditional agronomic practice, which if utilized correctly, can contribute significantly to reduce pest problems and consequently increase crop production. In recent years, intercropping is becoming popular as it offers the possibility of yield increase compared to monocropping (Egbe and Adeyemo, 2006; Saddam, 2009), such as peanut yields were increased by $39 \%$ and $35 \%$, respectively when intercropped with Atractylodes lancea and Euphorbia pekinensis, respectively, in a field experiment (Dai et al., 2009). In addition, intercropping also helps maintain the soil fertility (Patra and Chatterjee, 1986), efficient use of nutrients (Nazir et al., 1997; Zhu et al., 2006), improve soil microbial communities (Song et al., 2006; Dai et al., 2009) and reduce weed problems (Baumann et al., 2002). At present, intercropping is one option for alleviating soil sickness. Su et al. (2008) suggested that rain fed rice could be intercropped with watermelon to alleviate soil sickness compared to watermelon monoculture by restraining pathogen (Fusarium oxysporum f.sp. cucumerinum) development and regulating the microflora in rhizosphere of watermelon. Similar phenomena have been observed for peanut intercropped with Atractylodes lancea and Euphorbia pekinensis (Dai et al., 2009). However, few studies have focused on the A. sinensis soil sickness (Zhang et al., 2010).

The aims of the study were: (1) to evaluate the feasibility of alleviate soil sickness in A. sinensis production through intercropping with garlic, (2) to estimate the effect of $A$. sinensis intercropped with garlic on the rhizosphere soil microbial communities, and the diversity of bacteria functional group, and (3) to examine the effect of $A$. sinensis intercropped with garlic on $A$. sinensis growth, antioxidant enzyme activity.

\section{Materials and Methods}

\section{Soil}

Top soil (about 0-20 cm) cropped with A. sinensis for two years, with known soil sickness problem was collected in March 2008 from the Qingshui village, Min county (1033 $34^{\prime}$ E, 34 $27^{\prime} \mathrm{N}, 2300 \mathrm{~m}$ above Mean Sea Level), Gansu province, China. Thirty plots of 30 by $30 \mathrm{~cm}$ were randomly selected to collect experimental soil from $14 \mathrm{~cm}$ depth. Analysis of the soil indicated that it contain $6.6 \mathrm{~g} \cdot \mathrm{Kg}^{-1}$ organic matter, $0.89 \mathrm{~g} \cdot \mathrm{Kg}^{-1}$ total $\mathrm{N}, 1.15 \mathrm{~g} \cdot \mathrm{Kg}^{-1}$ total $\mathrm{P}, 20.74$ $\mathrm{g} \cdot \mathrm{Kg}^{-1}$ total $\mathrm{K}, 29.26 \mathrm{mg} \cdot \mathrm{Kg}^{-1}$ alkali-hydrolyzable $\mathrm{N}$ and $15.84 \mathrm{mg} \cdot \mathrm{Kg}^{-1}$ rapidly available $\mathrm{P}$ with $\mathrm{pH}=7.7$. The soil was screened through a $1 \mathrm{~mm}$ sieve for removing the plant residues and stones.

\section{Pot Experiment}

The experiment was carried out at the experimental site of the Institute of Radix Angelicae Sinensis in Min County, Gansu province in China, during the growing season (April to October) of 2008. The average temperatures for day and night were 24 and $13^{\circ} \mathrm{C}$, and the light and dark periods were 14 and $10 \mathrm{~h}$ each day during the whole growing season, respectively. No fertilization was applied during the experiment. A. sinensis grown alone served as the control.

Plastic pots $(30 \times 30 \times 28 \mathrm{~cm})$ were used, and each pot contained $10 \mathrm{Kg}$ of soil, and the pots were embedded into the soil leaving the top of the pot at the same height with the ground for eliminating the effect by the external conditions, using a completely randomized design. Four A. sinensis seedlings were planted into each pot under control, four $A$. sinensis seedlings with six seeds of garlic were planted in each pot under treatment, garlic was planted along the edge of pots. The pots were watered by drip irrigation when necessary, during the experiment.

\section{Sampling}

The stem height was measured using the tap measure at 18 days (8 May), 65 days (23 June) and 107 days (4 August) after seedling emergence, respectively. At seedling stage (23 June), healthy leaves of $A$. sinensis were collected, and stored at $4{ }^{\circ} \mathrm{C}$ until analyzed for antioxidant enzyme activity. At harvest stage (25 October), the plants were harvested and divided into shoot and root, and dried in an oven at $65^{\circ} \mathrm{C}$ to constant weight.

At seedling stage (23 June), rootstock thickening (15 August) and harvest stage (25 October), the soil adhering to the root, designated as 'rhizosphere soil' (Fujii et al., 2005), was collected, and the soil samples were mixed, sieved through a $1 \mathrm{~mm}$ mesh sieve. The soil samples were stored in refrigerator at $4^{\circ} \mathrm{C}$ until analyzed.

\section{Antioxidant Enzyme Activity and Lipid Peroxidation Determination in Leaves of $A$. Sinensis}

Extraction and activity determination of antioxidant enzyme were carried out following the method of Nakano and Asada 
(1981). Commonly, weighed $0.5 \mathrm{~g}$ of leaf material, and homogenized with $10 \mathrm{~mL}$ extraction buffer containing 50 $\mathrm{mM}$ phosphate buffer ( $\mathrm{pH} 7.4), 1 \mathrm{mM}$ ethylene diamine tetraacetic acid, $1 \mathrm{~g}$ polyvinyl pyrrolidone and $0.5 \%(\mathrm{v} / \mathrm{v})$ triton $\times 100$. The homogenate was centrifuged for $20 \mathrm{~min}$ at $12000 \mathrm{~g}$ and the supernatant obtained was used for analysis of enzyme activity.

Superoxide dismutase activity was measured by its ability to inhibit the photochemical reaction of nitroblue tetrazolium at $560 \mathrm{~nm}$ (Becana et al., 1986). One unit of SOD activity was defined as the enzyme amount causing $50 \%$ inhibition of NBT reduction. SOD activity is expressed as units per mg fresh mass of leaves.

Peroxidase activity was measured by monitoring the increase in absorbance at $470 \mathrm{~nm}$ due to guaiacol oxidation at $25^{\circ} \mathrm{C}$ (Becana et al., 1986). One unit of POD activity was defined as the increase in absorbance at $470 \mathrm{~nm}$ for $1 \mathrm{~min}$ due to guaiacol oxidation. POD activity expressed as units per min per g FM.

Catalase activity was assayed by monitoring the disappearance of $\mathrm{H}_{2} \mathrm{O}_{2}$ at $240 \mathrm{~nm}$ at $25^{\circ} \mathrm{C}$ (Becana et al. 1986). One unit of CAT activity was defined as the decrease at $240 \mathrm{~nm}$ for $1 \mathrm{~min}$ due to $\mathrm{H}_{2} \mathrm{O}_{2}$ consumption. CAT activity expressed as units per min per $\mathrm{g}$ FM.

The content of malondialdehyde (MDA) was determined by TBA test (Zhou et al., 2004).

\section{Yield and Quality of $A$. sinensis}

At harvest stage (25 October), all plants in pot were taken out of the soil and separated into shoots (leaves and stems were combined) and roots. Roots were first cleaned using distilled water. Then the sample was oven-dried at $60^{\circ} \mathrm{C}$ for $48 \mathrm{~h}$ and weighed. Content of essential oils and alcoholsoluble extract were measured according to Zhang et al. (2010).

\section{Enumeration of Culturable Microbial Populations in Rhizosphere Soil of $A$. sinensis}

Enumeration of culturable microbial populations was determined with traditional plate-dilution frequency technique on agar media in Petri plates (Harris and Sommers, 1968). Well mixed $0.05 \mathrm{~mL}$ samples of dilutions from $10^{-3}$ to $10^{-7}$ (in sterile deionized water) were spread in triplicate onto the following media for culturable microbe enumerations, bacteria were determined in the culture medium of Beef-cream and Peptone, actinomycete were determined in the culture medium of improved Gao 1, fungi on Martin's agar, azobacter was determined on AshbySucrose agar medium, ammonifying bacteria on protein agar medium, aerobic cellulose-decomposing bacteria on agar according to Waksman, organic phosphorussolubilizing bacteria on Meng Jina's agar, inorganic phosphorus-solubilizing bacteria on the culture medium of calcigenol simple and glucose, potassium-solubilizing bacteria on potassium aluminium silicate agar $(\mathrm{Xu}$ and Zheng, 1986).

\section{Analysis of Functional Group Diversity in Rhizosphere Soil of $A$. sinensis}

Enumeration of the functional group was determined with traditional plate-dilution frequency technique. The characteristic parameters including abundance, community diversity and evenness, and dominance concentration were calculated according to the type and amount of functional group (Magurran, 1988):

(1). Abundance $\left(\mathrm{P}_{\mathrm{i}}\right)$ was calculated by BergerParker method as $\mathrm{P}_{\mathrm{i}}=\mathrm{N}_{\mathrm{i}} / \mathrm{N}$, where $\mathrm{N}_{\mathrm{i}}$ represent the number of individuals in a cluster (or species) divided by the total number of isolates in the sample being analyzed. When $\mathrm{P}_{\mathrm{i}}>0.10$ as dominant groups, $0.01<\mathrm{P}_{\mathrm{i}} \leq 0.10$ as common groups, $\mathrm{P}_{\mathrm{i}} \leq 0.01$ as scarce groups (Shen et al., 2004).

(2). Community diversity $(\mathrm{H})$ was calculated by Shannon-Wiener method (Klemedtsson et al., 1987) as:

$\mathrm{H}=-\sum_{i=1}^{n} P i \ln P i$, where $P i$ represents the proportion of individuals of a given species.

(3). Community evenness (J) was calculated by Pielou method as $J=H / l n S$. S stand for the species number in soil microbe communities.

(4). Dominance concentration (C) was calculate by Pielou method as $\mathrm{C}=\sum \mathrm{P}_{\mathrm{i}}^{2}$.

\section{Statistical Analysis}

Each treatment was replicated three times. Analysis of variance for the data was performed by the general linear procedure of the SPSS system. Means were compared by LSD at $\mathrm{P}<0.05$ level.

\section{Results}

\section{Plant Properties}

Plant height: Mixed cropping had no effect on emergence time and rate of seedling emergence (data not shown). Analysis of plant height revealed a significant progressive increase in the intercropping treatment at each measured stage (Table 1). The root and shoot dry weight of $A$. sinensis were significantly increased (84.46 and $34.41 \%$, respectively) when $A$. sinensis plants were grown with garlic as compared to the control (Fig. 1).

\section{Antioxidant Enzyme Activity and Lipid Peroxidation in Leaves}

Compared with the control, the activity of SOD, POD and 
Table 1: Effect of intercropping A. sinensis with garlic on plant height (cm) of A. sinensis

\begin{tabular}{llll}
\hline Treatment & \multicolumn{2}{c}{ Days after seedling } \\
\cline { 2 - 4 } & $20 \mathrm{~d}$ & $65 \mathrm{~d}$ & $105 \mathrm{~d}$ \\
\hline Monocropping & $3.14 \pm 0.15^{\mathrm{b}}$ & $27.98 \pm 0.28^{\mathrm{b}}$ & $29.18 \pm 0.29^{\mathrm{b}}$ \\
Intercropping & $3.60 \pm 0.15^{\mathrm{a}}$ & $30.14 \pm 0.56^{\mathrm{a}}$ & $32.75 \pm 0.66^{\mathrm{a}}$ \\
\hline Lines in columns denoted by different letters are significantly different at $P<0.05$ according to least significant difference tests
\end{tabular}

Table 2: Effect of intercropping A. sinensis with garlic on antioxidant enzyme activity and lipid peroxidation of $A$. sinensis leave

\begin{tabular}{llll}
\hline Treatment & SOD $\left(\mathrm{U} \cdot \mathrm{mg}^{-1} \mathrm{FM}\right)$ & POD $\left(\mathrm{U} \cdot \mathrm{min}^{-1} \mathrm{~g}^{-1} \mathrm{FM}\right)$ & $\left.\mathrm{CAT}^{\mathrm{N}} \cdot \mathrm{min}^{-1} \mathrm{~g}^{-1} \mathrm{FM}\right)$ \\
\hline Monocropping & $0.65 \pm 0.031^{\mathrm{b}}$ & $6.53 \pm 0.256^{\mathrm{b}}$ & $100.39 \pm 5.211^{\mathrm{b}}$ \\
Intercropping & $1.17 \pm 0.057^{\mathrm{a}}$ & $22.41 \pm 1.133^{\mathrm{a}}$ & $137.66 \pm 6.404^{\mathrm{a}}$ \\
\hline Lines in column & $2.73 \pm 0.035^{\mathrm{a}}$ & $2.41 \pm 0.067^{\mathrm{b}}$ \\
\hline
\end{tabular}

Lines in columns denoted by different letters are significantly different at $P<0.05$ according to least significant difference tests

Table 3: Effect of intercropping A. sinensis with garlic on yield and quality of A.sinensis

\begin{tabular}{llll}
\hline Treatment & Yield $\left(\mathrm{g}^{-1} \cdot\right.$ plant $)$ & Essential oil content $(\%)$ & Extract content $(\%)$ \\
\hline Monocropping & 3.18 & 0.54 & 50.29 \\
Intercropping & 5.42 & 0.81 & 55.42 \\
\hline
\end{tabular}

CAT in leaves of A. sinensis was significantly increased, but the content of MDA was significantly decreased in intercropping treatment (Table 2).

\section{Yield and Quality}

Intercropping treatment significantly increased the yield, content of essential oils and alcohol-soluble extract by $70.13,50.00$ and $10.20 \%$, respectively as compared to monocropped control (Table 3).

\section{Enumeration of Culturable Microbial Populations in Rhizosphere Soil of $A$. sinensis}

As shown in Table 4, the number of culturable bacteria in the intercropping treatment increased significantly, as compared with the control at both seedling and rootstock thickening stages, while decreased significantly at harvest stage. For actinomycete and fungi, no significant difference was found at both seedling and rootstock thickening stages between intercropping treatment and the control, while have significant decrease at the harvest stage.

\section{Enumeration of Bacteria Functional Groups in Rhizosphere Soil of $A$. sinensis}

This study indicated that intercropping treatment changed the number of bacteria functional groups in rhizosphere soil of A. sinensis. The number of $\mathrm{AB}$ was significantly lower than that of the control at all determined stages, decreasing by $17.25,47.26$ and $22.01 \%$, respectively (Table 5 ). On the contrary, the number of IPSB in intercropping soil was increased by 20.48, 49.46 and $20.05 \%$, respectively compared with the control. The number of ACDB and OPSB was not significantly different between intercropping and the control at the seedling and harvest stages, but a

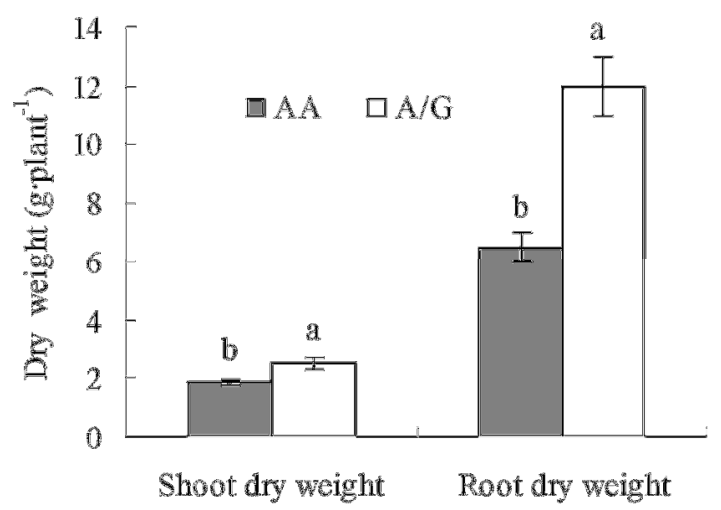

Fig. 1: Biomass (dry weight, g) of shoot and root of $A$. sinensis at rootstock thickening stage at different treatment. Within each plant component, vertical bars (s.e.) with the same letter are not significantly different $(P<0.05)$

significant difference was recorded at the rootstock thickening stage, with treatment increasing by 23.19 and $103.44 \%$, respectively compared with the control. Nevertheless, the number of KSB was not significantly different between intercropping and the control at the rootstock thicken stage, but significanly increased (19.06 and $75.59 \%$, respectively) at both seedling and harvest stage in treatment, as compared with the control.

\section{Analysis of Functional Group Diversity in Rhizosphere Soil of $A$. sinensis}

As shown in Table 6, A. sinensis intercropping with garlic decreased slightly the abundance of $\mathrm{AB}$ in rhizosphere soil of A. sinensis at all growth stages compared with the control, while the abundance of ACDB, OPSB, IPSB and KSB was increased markedly. 
Table 4: Population of microorganisms in rhizosphere soil at different growth stage of A. sinensis

\begin{tabular}{|c|c|c|c|c|c|c|c|c|c|}
\hline \multirow[t]{2}{*}{ Treatment } & \multicolumn{3}{|c|}{ Seedling stage } & \multicolumn{3}{|c|}{ Rootstock thickening stage } & \multicolumn{3}{|c|}{ Harvest stage } \\
\hline & $\begin{array}{l}\text { Bacteria } \\
\left(\times 10^{5} \mathrm{cfu} \cdot \mathrm{g}^{-1}\right)\end{array}$ & $\begin{array}{l}\text { Actinomycete } \\
\left(\times 10^{4} \mathrm{cfu} \cdot \mathrm{g}^{-1}\right)\end{array}$ & $\begin{array}{l}\text { Fungi } \\
\left(\times 10^{2} \mathrm{cfu} \cdot \mathrm{g}^{-1}\right)\end{array}$ & $\begin{array}{l}\text { Bacteria } \\
\left(\times 10^{5} \mathrm{cfu} \cdot \mathrm{g}^{-1}\right)\end{array}$ & $\begin{array}{l}\text { Actinomycete } \\
\left(\times 10^{4} \mathrm{cfu} \cdot \mathrm{g}^{-1}\right)\end{array}$ & $\begin{array}{l}\text { Fungi } \\
\left(\times 10^{2} \mathrm{cfu} \cdot \mathrm{g}^{-1}\right)\end{array}$ & $\begin{array}{l}\text { Bacteria } \\
\left(\times 10^{5} \mathrm{cfu} \cdot \mathrm{g}^{-1}\right)\end{array}$ & $\begin{array}{l}\text { Actinomycete } \\
\left(\times 10^{4} \mathrm{cfu} \cdot \mathrm{g}^{-1}\right)\end{array}$ & $\begin{array}{l}\text { Fungi } \\
\left(\times 10^{2} \mathrm{cfu} \cdot \mathrm{g}^{-1}\right)\end{array}$ \\
\hline Monocropping & $43.96 \pm 2.74^{\mathrm{b}}$ & $26.10 \pm 2.48^{\mathrm{a}}$ & $31.61 \pm 2.86^{\mathrm{a}}$ & $58.32 \pm 5.44^{\mathrm{b}}$ & $17.76 \pm 0.74^{\mathrm{a}}$ & $20.88 \pm 2.36^{\mathrm{a}}$ & $35.41 \pm 1.46^{\mathrm{a}}$ & $2.90 \pm 0.15^{\mathrm{a}}$ & $17.19 \pm 1.33^{\mathrm{a}}$ \\
\hline Intercropping & $72.25 \pm 3.90^{\mathrm{a}}$ & $24.95 \pm 1.17^{\mathrm{a}}$ & $35.78 \pm 2.63^{\mathrm{a}}$ & $89.53 \pm 4.09^{\mathrm{a}}$ & $17.94 \pm 1.22^{\mathrm{a}}$ & $20.95 \pm 1.59^{\mathrm{a}}$ & $24.18 \pm 0.66^{\mathrm{b}}$ & $2.19 \pm 0.15^{\mathrm{b}}$ & $13.40 \pm 0.68^{b}$ \\
\hline
\end{tabular}

Table 5: Populations of bacteria functional groups in rhizosphere soil at different growth stages of A. sinensis

\begin{tabular}{lllllll}
\hline Growth stages & Treatment & $\mathrm{AB}\left(\times 10^{4} \mathrm{cfu} \cdot \mathrm{g}^{-1}\right)$ & ACDB $\left(\times 10^{3} \mathrm{cfu} \cdot \mathrm{g}^{-1}\right)$ & OPSB $\left(\times 10^{2} \mathrm{cfu} \cdot \mathrm{g}^{-1}\right)$ & IPSB $^{\left(\times 10^{2} \mathrm{cfu} \cdot \mathrm{g}^{-1}\right)}$ & KSB $\left(\times 10^{2} \mathrm{cfu} \cdot \mathrm{g}^{-1}\right)$ \\
\hline Seedling stage & Monocropping & $36.52 \pm 3.16^{\mathrm{a}}$ & $21.55 \pm 1.04^{\mathrm{a}}$ & $14.67 \pm 1.91^{\mathrm{a}}$ & $26.90 \pm 0.43^{\mathrm{b}}$ & $21.30 \pm 1.14^{\mathrm{b}}$ \\
& Intercropping & $30.22 \pm 2.79^{\mathrm{b}}$ & $21.22 \pm 1.91^{\mathrm{a}}$ & $12.65 \pm 0.49^{\mathrm{a}}$ & $32.41 \pm 0.35^{\mathrm{a}}$ & $25.36 \pm 2.03^{\mathrm{a}}$ \\
Rootstock thickening stage & Monocropping & $21.20 \pm 1.79^{\mathrm{a}}$ & $12.85 \pm 0.62^{\mathrm{b}}$ & $6.68 \pm 1.33^{\mathrm{b}}$ & $8.31 \pm 0.33^{\mathrm{b}}$ & $14.16 \pm 1.56^{\mathrm{a}}$ \\
& Intercropping & $11.18 \pm 1.72^{\mathrm{b}}$ & $15.83 \pm 0.57^{\mathrm{a}}$ & $13.59 \pm 1.23^{\mathrm{a}}$ & $12.42 \pm 0.92^{\mathrm{a}}$ & $15.61 \pm 0.65^{\mathrm{a}}$ \\
Harvest stage & Monocropping & $26.76 \pm 0.58^{\mathrm{a}}$ & $3.42 \pm 0.06^{\mathrm{a}}$ & $43.21 \pm 2.19^{\mathrm{a}}$ & $8.53 \pm 1.23^{\mathrm{b}}$ & $48.06 \pm 1.34^{\mathrm{b}}$ \\
& Intercropping & $20.87 \pm 0.99^{\mathrm{b}}$ & $3.38 \pm 0.10^{\mathrm{a}}$ & $46.87 \pm 2.07^{\mathrm{a}}$ & $10.24 \pm 0.40^{\mathrm{a}}$ & $84.39 \pm 0.73^{\mathrm{a}}$ \\
\hline
\end{tabular}

Where CFU: Colony forming units; AB: Ammonifying bacteria; ACDB: Aerobic cellulose-decomposing bacteria; OPSB: organic phosphorus-solubilizing bacteria; IPSB: Inorganic phosphorus-solubilizing bacteria; KSB: Potassium-solubilizing bacteria

Lines in columns at the same stage denoted by different letters are significantly different at $P<0.05$ according to least significant difference tests

Table 6: Parameters of bacteria functional groups diversity in rhizosphere soil at different growth stages of $A$. sinensis

\begin{tabular}{|c|c|c|c|c|c|c|c|c|c|c|}
\hline \multirow[t]{2}{*}{ Growth stages } & \multirow[t]{2}{*}{ Treat. } & \multicolumn{5}{|c|}{ Abundance (Pi) } & \multirow{2}{*}{$\begin{array}{l}\text { Total individual } \\
\text { No. }(\mathrm{N}) \times 10^{4}\end{array}$} & \multirow{2}{*}{$\begin{array}{l}\text { Community } \\
\text { diversity }(\mathrm{H})\end{array}$} & \multirow{2}{*}{$\begin{array}{l}\text { Evenness } \\
(\mathrm{J})\end{array}$} & \multirow[t]{2}{*}{ Concentration(C) } \\
\hline & & $\overline{\mathrm{AB}}$ & ACDB & OPSB & IPSB & KSB & & & & \\
\hline \multirow[t]{2}{*}{ Seedling stage } & Monocropping & 0.9238 & 0.0602 & 0.0037 & 0.0068 & 0.0054 & 39.53 & 0.3254 & 0.2022 & 0.8572 \\
\hline & Intercropping & 0.9145 & 0.0642 & 0.0038 & 0.0098 & 0.0077 & 33.05 & 0.3620 & 0.2249 & 0.8406 \\
\hline \multirow{4}{*}{$\begin{array}{l}\text { Rootstock } \\
\text { thickening stage } \\
\text { Harvest stage }\end{array}$} & Monocropping & 0.9308 & 0.0564 & 0.0029 & 0.0036 & 0.0062 & 22.78 & 0.2981 & 0.1852 & 0.8696 \\
\hline & Intercropping & 0.8481 & 0.1201 & 0.0103 & 0.0097 & 0.0118 & 13.18 & 0.5390 & 0.3349 & 0.7340 \\
\hline & Monocropping & 0.9523 & 0.0122 & 0.0154 & 0.0030 & 0.0171 & 28.10 & 0.2515 & 0.1563 & 0.9076 \\
\hline & Intercropping & 0.9225 & 0.0149 & 0.0207 & 0.0045 & 0.0373 & 22.62 & 0.3646 & 0.2265 & 0.8531 \\
\hline
\end{tabular}

Where AB: Ammonifying bacteria; ACDB: Aerobic cellulose-decomposing bacteria; OPSB: organic phosphorus-solubilizing bacteria; IPSB: Inorganic phosphorus-solubilizing bacteria; KSB: Potassium-solubilizing bacteria

Although the total population of functional groups in rhizosphere soils of $A$. sinensis intercropping garlic was lower than in the control, community diversity and evenness were increased by $11.25-80.81$ and $11.22-80.83 \%$, respectively at all growth stages, whereas dominance concentration was decreased by $1.94-15.60 \%$ (Table 6 ).

\section{Discussion}

Long-term continuous cropping changed soil microbial community structure and diversity, and soil physicochemical property, which result in the negative effect on crop growth, yield and quality (Ryszkowski et al., 1998; Sun et al., 2001; Monneveux et al., 2006). However, diverse intercropping system can manage crop disease and improve crop production (Govaerts et al., 2006). In this study, the root and shoot dry weight of $A$. sinensis were significantly increased when $A$. sinensis plants were grown with garlic as compared to the control. This indicated that intercropping garlic could increase primary product of $A$. sinensis under continuous cropping condition. Similar trends have also been found in mustard (Sarker et al., 2007), Chinese cabbage (Cai et al., 2011) and geraium (Singh et al., 2011).

Soil microorganisms play an important role in the soil ecosystem, and to a certain extent, soil microbial community play an important role in plant growth and metabolic functions of soil (Hagn et al., 2003). Commonly, continuous cropping result in increase in fungi and decrease in bacteria as well as decrease of bacteria to fungi ratio, and thereby accelerate abundance of soil borne pathogens around plant roots (Ryszkowski et al., 1998; Dai et al., 2009). The above mentioned changes in types or amounts of soil microorganisms have wide impact on soil quality, and consequently on crop production. This study revealed that the number of bacteria increased significantly by intercropping together with decrease in the number of fungi, and the ratio of bacteria to fungi was higher than that of the control. This result indicated that garlic plants might change the status of soil microorganisms, which were beneficial to a healthy soil environment for $A$. sinensis plants, and this corresponded with improved growth of A. sinensis (Table 1, 2 and 3; Fig. 1).

Plants generate more reactive oxygen species (ROS) and stimulate resistance responses of plants when exposed to the stressful conditions (Thoma et al., 2003). These ROS are either toxic by-products of aerobic metabolism or regulators of growth, development and the defense pathways (Ding et al., 2007; Zhang et al., 2013). Toxic ROS 
can affect membrane permeability, induce lipid peroxidation, and ultimately lead to programmed cell death. In fact, plants possess efficient systems for scavenging ROS that protect them from destructive oxidative reactions (Olmos et al., 1994). As part of this system, antioxidant enzymes are key elements in the defense mechanisms. The activity of antioxidant enzymes has been reported to decrease under continuous cropping of cucumber (Zhang et al., 2007) and grape (Guo et al., 2010), but increases in pepper (Hou et al., 2006). In our previous study, the activity of antioxidant enzymes (SOD, POD and CAT) decreased under continuous cropping condition, which is in agreement with results obtained from cucumber (Zhang et al., 2007) and grape (Guo et al., 2010). In present studies, activities of SOD, POD and CAT of $A$. sinensis were increased in the intercropping system along with the improved of plant growth. MDA, an indicator of stress damage, is produced during the peroxidation of membrane lipids (Ohkawa et al., 1979). In our study, intercropping decreased the MDA content, and this was consistent with the results of $\mathrm{Su}$ et al. (2008). This suggested enhanced growth of A. sinensis by intercropping over continuous cropping condition might be due to increased antioxidant enzyme activity, which further improve the ability of plant for scavenging ROS.

\section{Conclusion}

The microflora in rhizosphere soil of A. sinensis was significantly improved in intercropping system through changed microbial community structure and increased community diversity and evenness of some functional groups. These alleviated the A. sinensis soil sickness by restraining the disease and regulating the protective enzymes system. The intercropping has some advantages on state of soil microorganisms and A. sinensis growth under continuous cropping condition. Further studies are needed to understand the implications of intercropping of $A$. sinensis with a variety of plants in field condition and long-term effect of the intercropping system.

\section{Acknowledgements}

This work is supported by Natural Science Foundation of China (31060182) and Agricultural Biotechnology Research and Application Development of Gansu province (GNSW2010-18).

\section{References}

Alías, J.C., T. Sosa, J.C. Escudero and N. Chaves, 2006. Autotoxicity against germination and seedling emergence in Cistus ladanifer L. Plant Soil, 282: 327-332

Baumann, D.T., L. Bastiaans and M.J. Kropff, 2002. Intercropping system optimization for yield, quality, and weed suppression combining mechanistic and descriptive models. Agron. J., 94: 734-742

Becana, M., P. Aparicio-Tejo, J.J. Irigoyen and M. Sanchez-Diaz, 1986. Some enzymes of hydrogen peroxide metabolism in leaves and root nodules of Medicago sativa. Plant Physiol., 82: 1169-1171
Benizri, E., S. Piutti, S. Verger, L. Pagès, G. Vercambre, J.L. Poessel and P. Michelot, 2005. Replant diseases: bacterial community structure and diversity in peach rhizosphere as determined by metabolic and genetic fingerprinting. Soil Biol. Biochem., 37: 1738-1746

Cai, H.J., S.Y. Li, K. Ryall, M.S. You and S. Lin, 2011. Effects of intercropping of garlic or lettuce with Chinese cabbage on the development of larvae and pupae of diamondback moth (Plutella xylostella). Afr. J. Agric. Res., 6: 3609-3615

Chen, C.Y., 2004. Trace elements in Taiwanese health food, Angelica keiskei and other products. Food Chem., 84: 545-549

Chen, H., H.R. Hao, J. Xiong, X.H. Qi, C.Y. Zhang and W.X. Lin, 2007. Effects of successive cropping Rehmannia glutinosa on rhizosphere soil microbial flora and enzyme activities. Chin. J. Appl. Ecol., 18: 2755-2759

Dai, C.C., H. Xie, X.X. Wang, P.D. Li, T.L. Zhang, Y.L. Li and X. Tao, 2009. Intercropping peanut with traditional Chinese medicinal plants improves soil microcosm environment and peanut production in subtropical China. Afr. J. Biotechnol., 8: 3739-3736

Ding, J., Y. Sun, C.L. Xiao, K. Shi, Y.H. Zhou and J.Q. Yu, 2007. Physiological basis of different allelopathic reactions of cucumber and figleaf gourd plants to cinnamic acid. J. Exp. Bot., 58: 3765-3773

Duan, A.M., G.S. Liu, D.L. Jiao and Y.N. Zhang, 2002. Resistant watermelon variety "Heixuanfeng" breeding. Tianjin Agric. Sci., 8: 21-23

Egbe, O.M. and M.O. Adeyemo, 2006. Estimation of the effect of intercropped pigeon pea on the yield and yield components of maize in Southern Guinea Savannah of Nigeria. J. Sustain. Dev.. Agric. Environ., 2: 107-119

Fujii, Y., A. Furubayashi and S. Hiradate, 2005. Rhizosphere soil method: a new bioassay to evaluate allelopathy in the field. In: Proceedings of the Fourth World Congress on Allelopathy 'Establishing the Scientific Base,' pp: 490-492. Haper, J.D.I., M. An and J.H. Kent, (eds.). Charles Sturt University, Wagga, NSW, Australia

Govaerts, B., M. Mezzalama, K.D. Sayre, J. Crossa, J.M. Nicol and J. Deckers, 2006. Long-term consequences of tillage, residue management, and crop rotation on maize/wheat root rot and nematode populations in subtropical highlands. Appl. Soil. Ecol., 32: 305-315

Guo, X.W., K. Li, H.G. Xie, Y.N. Sun, X.X. Hu and L.H. Zhang, 2010. Effect of sterilized replant soil on grape growth and root exudation characteristics. J. Fruit. Sci., 27: 29-33

Haggag, W.M., 2002. Sustainable agriculture management of plant diseases. J. Biol. Sci., 2: 280-284

Hagn, A., K. Pritsch, M. Schloter and J.C. Munch, 2003. Fungal diversity in agricultural soil under different farming management systems, with special reference to biocontrol strains of Trichoderma spp. Biol. Fert. Soils, 38: 236-244

Harris, R.F. and L.E. Sommers, 1968. Plate-dilution frequency technique for assay of microbial ecology. Appl. Microbial., 16: 330-334

Hassan, M.S., A.H. El-Behadli and I.S. Alsaadawi, 1989. Citrus replant problem in Iraq I . Possible role of soil fungi and nematodes. Plant Soil, 116: 151-155

He, C.N., W.W. Gao, J.X. Yang, W. Bi, X.S. Zhang and Y.J. Zhao, 2009. Identification of autotoxic compounds from fibrous roots of Panax quinquefolium L. Plant Soil, 318: 63-72

Hou, Y.X., B.L. Zhou, X.L. Wu, Y.W. Fu and Y.Y. Wang, 2006. Effect of soil sterilization on preventing contiuous pepper cropping obstacles. Chin. J. Ecol., 25: 340-342

Hu, Y.L., S.L. Wang and D.H. Zeng, 2006. Effects of single Chinese fir and mixed leaf litters on soil chemical, microbial properties and soil enzyme activities. Plant Soil, 282: 379-386

Klemedtsson, L., P. Berg, M. Clarholm, J. Schnürer and T. Rosswall, 1987. Microbial nitrogen transformations in the root environment of barley. Soil Biol. Biochem., 19: 551-558

Lv, W.G., C.L. Zhang, F. Yuan and Y. Peng, 2000. Preliminary study on relieving the obstacles of continuous cropping cucumber in greenhouse by inoculating. Acta Agric. Boreali-Sin., 15: 153-156

Ma, R.J., X. Wang and X.L. Chen, 2002. Advances in research of Angelica sinensis. Chin. Tradit. Herbal. Drugs., 33: 280-282 
Magurran, A.E., 1988. Ecological Diversity and Its Measurement, pp: 86-97. Princeton University Press, New Jersey, USA

Manici, L.M., C. Ciavatta, M. Kelderer and G. Erschbaumer, 2003. Replant problems in South Tyrol: role of fungal pathogens and microbial population in conventional and organic apple orchards. Plant Soil, 256: $315-324$

Monneveux, P., E. Quillerou, C. Sanchez and J. Lopez-Cesati, 2006. Effect of zero tillage and residues conservation on continuous maize cropping in a subtropical environment (Mexico). Plant Soil, 279: 95-105

Nakano, Y. and K. Asada, 1981. Hydrogen peroxide is scavenged by ascorbate-specific peroxidase in spinach chloroplast. Plant Cell Physiol., 22: 867-880

Nazir, M.S., E. Elahi, A. Jabbar, M. Saeed and R. Ahmad, 1997. Bioeconomic assessment of different wheat-based intercropping systems. Pak. J. Agric. Sci., 34: 62-64

Ofori, F. and W.R. Stern, 1987. Cereal-legume intercropping systems. Adv. Agron., 41: 41-90

Ohkawa, H., N. Ohishi and K. Yagi, 1979. Assay for lipid peroxides in animal tissue by thiobarbituric acid reaction. Anal. Biochem., 95 $351-358$

Olmos, E., J.A. Hernandez, F. Sevilla and E. Hellin, 1994. Induction of several antioxidant enzymes in the selection of a salt-tolerant cell line of Pisum sativum. J. Plant Physiol., 144: 594-598

Patra, A.P. and B.N. Chatterjee, 1986. Intercropping of soybean with rice, maize and pigeonpea in the plains of West Bengal. Ind. J. Agric. Sci. 56: 413-417

Ryszkowski, L., L. Szajdak and J. Karg, 1998. Effects of continuous cropping of rye on soil biota and biochemistry. Crit. Rev. Plant. Sci., 17: $225-244$

Saddam, A.L.D., 2009. Effect of intercropping of zea maize with potato Solanum tuberosum L. on potato growth and on the productivity and land equivalent ration of potato and zea maize. Agron. J., 4: 164-170

Sarker, P.K., M.M. Rahman and B.C. Das, 2007. Effect of intercropping of mustard with onion and garlic on aphid population and yield. J. BioSci., 15: 35-40

Segiun, P., C.C. Sheaffer, M.A. Schmitt, M.P. Russelle, G.W. Randall, P.R. Peterson, T.R. Hoverstad, S.R. Quiring and D.R. Swanson, 2002. Alfalfa autotoxicity: Effects of reseeding delay, original stand age and cultivar. Agron. J., 94: 775-781

Shen, F.F., X.L. Han and S.L. Fan, 2004. Changes in microbial flora and bacterial physiological group diversity in rhizosphere soil of transgenic Bt cotton. Acta. Ecol. Sin., 24: 432-437 (in Chinese)

Singh, S., M. Ram, K. Singh and B.S. Verma, 2011. Growth and yield of Geranium (Pelargonium graveolens) and garlic (Allium sativum) in intercropping system. Ind. J. Agric. Res., 45: 179-187

Song, Y.N., M. Petra, F.S. Zhang, X.G. Bao and L. Li, 2006. Effect of intercropping on bacterial community composition in rhizoshpere of wheat (Triticum aestivum L.), maize (Zea mays L.) and faba bean (Vicia faba L.). Acta Ecol. Sin., 26: 2268-2274

Su, S.M., L.H. Ren, Z.H. Hu, X.M. Yang, Q.W. Huang, Y.C. Xu, J. Zhou and Q.R. Shen, 2008. Effects of intercropping watermelon with Rain Fed Rice on Fusarium wilt and the microflora in the rhizosphere soil. Sci. Agric. Sin., 41: 704-712

Sun, X.S., H.S. Feng, S.B. Wan and X.Q. Zuo, 2001. Changes of main microbial strains and enzymes activity in peanut continuous cropping soil and their interactions. Acta Agron. Sin., 27: 617-621
Thoma, I., C. Loeffler, A.K. Sinha, M. Gupta, M. Krischke, B. Steffan, T. Roitsch and M.J. Mueller, 2003. Cyclopentenone isoprostanes induced by reactive oxygen species trigger defense gene activation and phytoalexin accumulation in plants. Plant J., 34: 363-375

Wu, H., J. Pratley, D. Lemerle, M. An and D.L. Liu, 2007. Autotoxicity of wheat (Triticum aestivum L.) as determined by laboratory bioassays. Plant Soil, 296: 85-93

Xu, G.H. and H.Y. Zheng, 1986. Handbook of Methods for Edaphon Analysis, pp: 102-135. China Agriculture Press, Beijing, China

Yao, H.Y., X.D. Jiao and F.Z. Wu, 2006. Effects of continuous cucumber cropping and alternative rotations under protected cultivation on soil microbial community diversity. Plant Soil, 284: 195-203

Yin, F.J., X.Y. Qu, W. Zeng and S. Shu, 2009. Study on the autointoxication of aquatic extracts from different parts of Coptis chinensis. J. Chin. Med. Mater, 32: 329-330

Young, C.C., 1984. Autointoxication in root exudates of Asparagus officinalis L. Plant Soil, 82: 247-253

Yu, J.Q. and Y. Matsui, 1994. Phytotoxic substances in root exudates of cucumber (Cucumis sativus L.). J. Chem. Ecol., 20: 21-31

Yu, J.Q., S.Y. Shou, Y.R. Qian, Z.J. Zhu and W.H. Hu, 2000. Autotoxic potential of cucurbit crops. Plant Soil, 223: 147-151

Zhang, C.L., Q. Sun and Q. Ye, 2005. Obstacle effect of continuous cropping on Salvia miltiorrhiza growth. Acta Bot. Bor-Occid. Sin., 25: $1029-1034$

Zhang, S.S., X.M. Yang, Z.S. Mao, Q.W. Huang, Y.C. Xu and Q.R. Shen, 2007. Effects of sterilization on growth of cucumber plants and soil microflora in a continuous mono-cropping soil. Acta. Ecol. Sin., 27: 1809-1817

Zhang, S.Y. and K.C. Cheng, 1989. Medicinal and aromatic plants. In: Biotechnology in Agriculture and Forestry, Bajaj, Y.P.S. (ed.). Springer, Heidelberg, Germany

Zhang, X.H., D.Y. Lang, E.H. Zhang, C.C. Bai and H.Z. Wang, 2013. Diurnal changes in photosynthesis and antioxidants of Angelica sinensis as influenced by cropping systems. Photosynthetica, 51: $252-258$

Zhang, X.H., E.H. Zhang and D.Y. Lang, 2011. Autotoxic compounds from rhizosphere soil of Humulus lupulus L. extracts: identification and biological activity. Agron. J., 103: 695-701

Zhang, X.H., E.H. Zhang and H.Z. Wang, 2009. Effect of continuous cropping on the essential oils of Angelica sinensis. Nat. Prod. Res. Dev. 21: $342-346$

Zhang, X.H., E.H. Zhang, X.Y. Fu, Y. Huang and D.Y. Lang, 2010. Autotoxic effects of Angelica sinensis (Oliv.) Diels. Allelopathy J., 26: $1-12$

Zhao, C.F., H. Liu and L.J. Yu, 2010. The effect of continuous cropping to soil bacterial community on Liriope root. Micro. Chin., 37: 487-491

Zhou, Y.H., J.Q. Yu, L.F. Huang and S. Nogués, 2004. The relationship between $\mathrm{CO}_{2}$ assimilation, photosynthetic electron transport and water-water cycle in chill-exposed cucumber leaves under low light and subsequent recovery. Plant Cell Environ., 27: 1503-1514

Zhu, H.Y., Z.D. Liu, C.R. Wang and Z.C. Zhong, 2006. Effects of intercropping with persimmon on the rhizoshpere environment of tea. Front. Agric. Chin., 4: 407-410

(Received 20 August 2013; Accepted 12 June 2014) 